\title{
Violation of Human Rights in Nigeria: An Appraisal of the Activities of the Transnational Oil Corporations in the Niger Delta Region
}

\author{
Ogwezzy Michael C*
}

\section{Abstract}

Non state actors play a significant role in international relations. They do not hold the characteristics of a legal sovereign but have some measure of control over a country's people and territories. Transnational corporations are non states actors with profit motive that operate in different sovereign states and continents in the world deriving their power most of the time from the law of these states. Economists, lawyers and social scientists alike have for a number of years agreed that foreign investments like TNCs have the potential to act as a catalyst for the promotion or violation of human rights, particularly in developing countries. This is even more so, considering that corporate investors are often not explicitly obliged under investment agreements to observe human rights even though they exert considerable power over individuals, communities and indigenous populations. Such assertions have strengthened the normative link between human rights violations and the activities of transnational corporations like the oil companies. It is on this premise that this paper discusses how the activities of transnational oil corporations in the Niger Delta region have led to violations of human rights and examines how the federal government of Nigeria through legislation has empowered these transnational oil companies to engage

* Lecturer, Department of Public International Law, Faculty of Law, Lead City University, Ibadan, Nigeria;ogwezzym@gmail.com 
in activities that lead directly to such flagrant violation of human rights.

Keywords: Environmental Pollution; Human Rights; Nigeria; Non State Actors; Transnational Corporations.

\section{Introduction}

It has been acknowledged that one of the most important aspects of the rise of post 1945 global capitalism has been the call for transnational corporations (hereinafter referred to as "TNCs") to conform to basic human rights principles. In November 1993, a Philadelphia law firm filed a $\$ 1.5$ billion class action suit with 46 plaintiffs from the oil producing Oriente region of Ecuador, on behalf of 30,000 Ecuadorian citizens, against Texaco Inc. Allegations of corporate irresponsibility associated with the company's oil operations were made in the suit. Serious illnesses, water contamination, and ecological destruction were attributed to the oil company. ${ }^{1}$

Large natural resource TNCs, including oil giants like Enron, ${ }^{2}$ Unocal, ${ }^{3}$ and Shell, ${ }^{4}$ have been dogged for years by allegations of

1 Michael J. Watts, Righteous Oil? Human Rights, the Oil Complex and Corporate Social Responsibility, ANNUAL REVIEW OF ENVIRONMENTAL RESOURCE 9.1, 9.2 (2005).

2 See Human Rights Watch, The Enron Corporation: Corporate COMPLICITY IN HUMAN RIGHTS VIOLATIONS (Human Rights Watch, 2012), available at http://www.hrw.org/reports/1999/enron/.

3 See Doe v. Unocal Corp. 1, 963 F. Supp. 880 (C.D. Cal. 1997); Doe v. Unocal Corp., 110 F. Supp. 2d 1294 (C.D. Cal. 2000); Doe v. Unocal Corp., 2002 WL 31063976 (9th Cir. 18 September, 2002) (aff'd in part, rev'd in part); Doe v. Unocal Corp II., 2003 WL 359787 (9th Cir. Feb. 14, 2003) (vacated) (unocal's relationship to the Burmese military and its culpability in human rights violations associated with efforts to build the Yadana oil pipeline have been subject to a long running Alien Tort Claims Act case in California).

4 Wiwa v. Royal Dutch Petroleum Co., 226 F.3d 88 (2nd Cir. 2000); Wiwa v. Royal Dutch Petroleum Co., 2002 U.S. Dist. LEXIS 3293 (S.D.N.Y. 2002) (finding that plaintiffs' allegations that Shell participated in deportation, forced exile and torture of the Ogoni people in Nigeria, as part of a 
illegal violence, forced labour, and support of armed conflicts in pursuit of their corporate interests. As private armies and as managers of mineral concessions, TNCs assume powers resembling those of states. Many of these TNCs activities have been the source of substantial allegations of human rights abuse. At other times, various TNCs have supported, funded and benefited from human rights violations perpetrated by the state. Rumour, anecdote and verified instances of sensational abuses have combined to create an impression that TNCs are beyond the reach of human rights law. ${ }^{5}$ The above situations at one time or the other have been experienced in the Niger Delta region of Nigeria.

\section{Transnational Corporations}

The term 'transnational corporation'6 refers to an economic entity or a group of economic entities operating in two or more countries, whatever the legal framework, the country of origin or the country or countries of activity, whether its activity is considered individually or collectively. Transnational corporations are legal persons in private law with multiple territorial implantations with a single centre for strategic decision making.7 "They can operate through a parent corporation with subsidiaries; can set up groups within a single economic sector, conglomerates, or alliances having diverse activities; can consolidate through mergers or acquisitions

widespread attack, satisfied a claim for crimes against humanity under the Alien Tort Claims Act).

5 Rebecca M. Bratspies, Organs of Society: A Plea for Human Rights Accountability for Transnational Enterprises and Other Business Entities, 13 MiCH. ST. J. INT'L L. 4-6 (2005).

6 Note that the terms "Transnational Corporations" and "Multinational Corporations" will be used interchangeably in the course of this paper. Both phrases mean the same, except for semantics.

7 Melik Özden, Transnational Corporations and Human Rights: What is at stake in the United Nations debate over The Norms on the Responsibilities of Transnational Corporations and other Business Enterprises with Regard to Human Rights 8, 9 (July 29, 2012), available at http://www.cetim.ch/ en/documents/bro2-stn-an.pdf (brochure prepared for the CETIM's Human Rights Program and Permanent Representative of the CETIM to the United Nations in Geneva Part of a series of the Human Rights Programme of the Europe-Third World Centre (CETIM)). 
or can create financial holding companies. These holding companies possess only financial capital invested in stock shares through which they control companies or groups of companies. In all cases (parent company with subsidiaries, groups, conglomerates, alliances and holding company), the decision making process for the most important matters is centralized. ${ }^{8}$ These corporations can establish domicile in one or several countries: in the country of the actual headquarters of the parent company, in the country where its principal activities are located and/or where the company is chartered. Transnational corporations are active in oil production services, as could be found in Niger Delta region of Nigeria. They are also into finance, communications, basic and applied research, culture, leisure etc. They operate in these areas simultaneously, successively or alternatively. They can segment their activities across various territories, acting through de facto or de jure subsidiaries and/or suppliers, subcontractors or licensees. ${ }^{9}$

8 See SEAd D. Murry, Principles of InTERnAtiOnAl LAW 62 (2006); see also Belgium v. Spain, 1979 I.C.J. 3, 168 (multinational Corporation (MNCs) by which is meant corporations with affiliated business in more than one country. They have become important actors in the international arena. While the corporation is deemed to have the nationality of the state where it is incorporated, the activities of the MNC (or TNCs) can be global in scope, and provide significant benefits by creating wealth in states where they operate. Through their investments and trade, MNCs create jobs, produce goods and services, introduce technologies, and develop markets. While much of the increased MNCs' activities since the 1990's has been among developed nations, a portion of that activity includes the movement of MNCs operations to the developing world to take advantage of a cheaper supply of labour and lax environmental and human rights laws).

9 Commission on Transnational Corporations, Development and International Economic Co-operation: Transnational Corporations Annexe: Proposed Text of the Draft Code of Conduct of Transnational Corporations 5, E/1990/94 Official Records of Economic and Social Council, 1990, Supp. No. 1, U.N. 1991. 


\section{The Niger Delta Region}

The Niger Delta area in Nigeria is situated in the Gulf of Guinea. It is the largest wetland in Africa and the third largest in the world consisting of flat low lying swampy terrain that is crisscrossed by meandering and anastomosing streams, rivers and creeks. It covers $20,000 \mathrm{~km}^{2}$ within wetlands of $70,000 \mathrm{~km}^{2}$ formed primarily by sediment deposition. It is home to 20 million people drawn from nine states namely Abia, Akwa Ibom, Bayelsa, Cross River, Delta, Edo, Imo, Ondo and Rivers states with 40 different ethnic groups. This floodplain constitutes $7.5 \%$ of Nigeria's total land mass. This incredibly well endowed ecosystem contains one of the highest concentrations of biodiversity on the planet, supporting abundant flora and fauna, arable terrain that can sustain a wide variety of crops, lumber or agricultural trees, and more species of freshwater fish than any ecosystem in West Africa. More than 70\% of Nigeria's crude oil and gas production is from this area. The region produces over $90 \%$ of Nigeria's foreign earnings through oil exploration activities. It plays host to most of the upstream and downstream oil related industries and non oil related industries that release tons of pollutants into the ecosystems. The pollution from the Niger Delta on a scale could be regarded as one of the worst among similar delta areas in the world. ${ }^{10}$

\section{TNCs and its Dominance on Host States and the Human Rights Implications}

The origin of the activities of TNCs in Niger Delta region of Nigeria can be effectively traced to 1956 . Today, there are over 606 oil fields in the Niger Delta, of which 360 are onshore and 246 offshore. Nigeria has been rated as one of the largest oil producer in Africa and the sixth largest in the world, averaging 2.7 million barrels per day $(\mathrm{bbl} / \mathrm{d})$ in 2006. Nigeria's economy is heavily dependent on

10 Godson Rowland Ana, Air Pollution in the Niger Delta Area: Scope, Challenges and Remedies, in THE IMPACT OF AIR POLlution ON HEALTH, ECONOMY, ENVIRONMENT AND AGRICULTURAL SOURCES 181, 182 (Mohamed K. Khallaf ed. 2011), available at http://cdn.intechopen.com/ pdfs/18639/ InTechAir_pollution_in_the_niger_delta_area_scope_challenges_and_rem edies.pdf. 
earnings from the oil sector, which provides $20 \%$ of GDP, $95 \%$ of foreign exchange earnings, and about $65 \%$ of budgetary revenues. ${ }^{11}$

TNCs have been expanding not only numerically but also financially. In 1998, the annual revenue of the top five corporations, was more than twice the gross domestic product of the 100 poorest countries in the world. ${ }^{12}$

The sheer size and enormous economic power of TNCs means they have the capacity to influence development policy. Due to the perceived benefits associated with them, political and economic decisions by elected governments are increasingly made to provide favourable environments for the investment and marketing needs of TNCs. Consequently, corporations are sometimes able to influence the domestic policy outcomes of host developing countries by threatening to move jobs overseas. This often raises questions about whether corporate power enables TNCs to effectively undermine human rights by circumventing domestic environmental standards and statutory laws. Moreover, the fear that firms will move jobs overseas and its impact on the economy can influence the degree to which developing countries will impose environmental regulations on multinational enterprises thereby giving way to free haven for the operations of TNCs. ${ }^{13}$

Again, as trade liberalization, privatization, and deregulation have fostered the expansion of business worldwide, experts have lamented that the nation state as an organizational entity is declining in power ${ }^{14}$ and that future international legal efforts to increase human rights protection should attempt to bypass the state

11 P. C. Nwilo \& O. T. Badejo, Impacts and Management of Oil Spill Pollution along the Nigerian Coastal Areas 4 (Aug. 6, 2012), available at http:/ / fig.net/pub/figpub/pub36/chapters/chapter_8.pdf.

$12 \mathrm{Id}$. at 3 .

13 J. Clapp, Transnational Corporations and Global Environmental Governance, in HANDBOOK Of Global EnviROnMENTAL Politics 1 (P. Dauvergne ed., 2005).

14 Christen Broecker, Better the Devil You Know: Home State Approaches to Transnational Corporate Accountability 165-167, INT'L LAW AND POLITICS (2008). 
altogether. 15 For these entities, "territory is not the cardinal organizing principle or national interests, the core driver." Yet traditional state methods of regulating corporate activity remain largely territorial, leading many to believe that domestic law's ability to enforce human right norms has been effectively thwarted.16 However, the increasing power and mobility of corporations is hardly a phenomenon that state actors are powerless to address. While the structure of TNCs does allow them to move their operations between worldwide facilities, making them slippery regulatory targets, 17 their innovative structure is not the sole factor contributing to their substantial freedom from state regulation. Rather, domestic political systems have either chosen to relinquish their control over businesses that operate in a global space or have simply neglected to exert control beyond their borders in the first place. Many business leaders have enormous economic and political power, allowing them to exercise political influence that is disproportionate to their numbers and to lobby for favourable regulatory schemes in the states that would otherwise be best positioned to control them. ${ }^{18}$ Certainly, such business

15 See David Kinley \& Junko Tadaki, From Talk to Walk: The Emergence of Human Rights Responsibilities for Corporations at International Law, 44 VA. J. INT'L L. 931, 933 (2004) (arguing that the current state based framework of international human rights law is inadequate to regulate powerful non state actors, and proposing direct international legal regulation of transnational corporations).

16 Beth Stephens, The Amorality of Profit: Transnational Corporations and Human Rights, 20 BERKELEY J. INT'L L. 45, 54 (2002).

17 Claudio Grossman \& Daniel D. Bradlow, Are We Being Propelled Towards a People-Centered Transnational Legal Order?, 9 AM. U. J. INT'L L. \& POL'Y 1, 8 (1993) (the fact that they have multiple production facilities means that TNCs can evade State power and the constraints of national regulatory schemes by moving their operations between their different facilities and the world. Again, apart from using the armed forces to maintain peace in the Niger Delta, the Nigerian government uses the oil pipeline Act of 1956, the Petroleum Act of 1969 and the Land Use Act of 1978, the Treason and Treasonable offences Decree of 1993 (now an Act of the National assembly) to intimidate and harass the Niger Delta peoples).

${ }_{18}$ Surya Deva, Acting Extraterritorially to Tame Multinational Corporations for Human Rights Violations: Who Should 'Bell the Cat'?, 5 MeLb. J. INT'L L. 37 
interests profoundly affect the behaviour of host states as well as home states, as the leaders of the host states often face considerable pressure to create an attractive environment for foreign investment. ${ }^{19}$ Yet business actors also exert powerful influences over home states, incentivizing them to structure the relations between their domestic investors and their foreign hosts in ways that heavily favour the former. ${ }^{20}$ The influence of business actors on state policies is similarly reflected at the international level, where states are often unwilling to support mechanisms that would constrain the actions of their own nationals abroad. ${ }^{21}$ As a result of the political and economic power of business actors, TNCs operating in capital importing countries are frequently able to infringe the human rights of the citizens of their host states with virtual impunity. ${ }^{22}$

(2004) (discussing the use of extraterritorial laws to regulate multinational corporations in the context of human rights).

${ }^{19}$ Erin Elizabeth Macek, Scratching the Corporate Back: Why Corporations Have No Incentive to Define Human Rights, 11 MinN. J. Global Trade 101, 103-104 (2002).

20 Stephens, supra note 16 at 54, 58 (Economic power carries with it a growing political clout. Corporations play influential direct and indirect roles in negotiations over issues ranging from trade agreements to international patent protections to national and international economic policy).

${ }^{21} I d$. at 81.

22 Jana Silverman \& Alvaro Orsatti, Holding Transnational Corporations Accountable for Human Rights Obligations: The Role of Civil Society, SOCIAL WATCH, Jul. 30, 2012, at 31, available at http://www.socialwatch.org/ sites/default/files/silverman-orsatti2009_eng.pdf (business enterprises, particularly transnational companies, are typically private, nongovernmental entities subject only to national laws in either the country where the company has its headquarters or in the host countries where the company has investments. Even though these companies may have significant presence in multiple countries, they are not technically considered to have international legal status, which is limited to states and certain intergovernmental organizations such as the European Union and the UN. This means that by and large they have not been subject to the rights and obligations of international law, including international human rights law). 


\section{Impact of the Operation of TNCs on Environment}

The social and environmental cost of oil production by transnational oil corporations has been very extensive. They include destruction of wildlife and biodiversity, loss of fertile soil, pollution of air and drinking water, degradation of farmland and damage to aquatic ecosystems, all of which have caused serious health problems for the inhabitants of the areas surrounding oil production. It is ironical that environmental regulations which are common practice in developed nations are often not followed due to the lack of power, wealth and equity of the affected communities. As a result, oil companies often evacuate inhabitants from their homelands, further marginalizing them. The system of oil production in Nigeria is skewed in favour of the multi nationals and government elite who are the direct recipients of revenue of oil production. As a result of environmental damage brought about by the activities of the oil companies, environmental hazards like erosion, flooding, land degradation, destruction of natural ecosystem, fisheries depletion caused by dredging, toxic waste into the rivers etc., are common phenomenon in the region. The local people can no longer take to farming and fishing which are their major occupations. As a result of the impact of oil production activities on the environment and the ecosystem of the region, the United Nations warned in a report that "the degree and rate of degradation are pushing the Delta towards ecological disaster" ${ }^{23}$

Under Nigerian law, local communities have no legal rights to oil and gas reserves in their territory. ${ }^{24}$ Moreover, their security of tenure and the protection of the right to an adequate standard of living, including housing, food and water, have been compromised

23 Nigerian Oil Curse of the Black Gold, (Jul. 29, 2012) http:// www7.nationalgeographic.com.

24 FED. REP. OF NigERIA CONST., Ch 4, §44 (3) ("Notwithstanding the foregoing provisions of this section, the entire property in and control of all minerals, mineral oils and natural gas in under or upon any land in Nigeria or in, under or upon the territorial waters and the Exclusive Economic Zone of Nigeria shall vest in the Government of the Federation and shall be managed in such manner as may be prescribed by the National Assembly"). 
by both constitutional provisions and a number of laws that give precedence to oil operations in terms of access to land. ${ }^{25}$

Section 44 of the 1999 Constitution states that:

The entire property in and control of all minerals, mineral oils and natural gas in, under or upon any land in Nigeria or in, under or upon the territorial waters and the Exclusive Economic Zone of Nigeria, shall vest in the Government of the Federation and shall be managed in such manner as may be prescribed by the National Assembly.

Under the Land Use Act 1978, all land is vested in the Governor of the State and it is lawful for the Governor "to revoke a right of occupancy for overriding public interest". Overriding public interest includes "the requirement of the land for mining purposes or oil pipelines or for any purpose connected therewith." 26 Communities living on the land cannot prevent this from occurring, and there is no provision in the law for consultation. Provisions within the Petroleum Act, 1990 and the Oil Pipelines Act, 1990 empower the federal government to grant access and use rights in relation to land, for the purposes of oil prospecting and mining. Once a company has been given a permit, licence or lease, the state government has to give access to the land. The communities are compensated according to a formula that primarily assesses value based on 'surface goods' lost. ${ }^{27}$ These are

25 Amnesty Int'l, Nigeria: Petroleum, Pollution and Poverty in the Niger Delta, AI Index AFR 44/017/2009 at 24 (Jun. 2009).

26 See The Land Use Act (1978), Cap. L.5 Laws of the Federation of Nigeria (LFN), 2004, §28 (1) and 28 (2) (c) and 28 (3) (b) (regulates ownership rights and tenure system of landholding).

27 (Under the Land Use Act, 1978, if a right of occupancy is revoked for purposes related to mining and oil, the occupier is entitled to compensation under the appropriate provisions of the relevant Mining or Oil laws. $\$ 36$ of the Petroleum Act states "holder of an oil exploration licence, oil prospecting licence or oil mining lease shall, in addition to any liability for compensation to which he may be subject under any other provision of this Act, be liable to pay fair and adequate compensation for the disturbance of surface or other rights to any person who owns or is in lawful occupation of the licensed or leased lands." \$20 of the Oil Pipelines Act, 1959 (Cap. O7, LFN 2004) states: "If a claim is made under § 6(3) of 10 
buildings, crops, economic trees and access to fishing grounds. The compensation calculations do not appear to consider the long term implications of loss of access to critical livelihood resources.

Moreover, the Land Use Act, 1978 bars the courts from addressing any concerns about the amount or adequacy of compensation paid to people who lose access to their land under the terms of the Act. ${ }^{28}$ The combination of the constitutional provisions relating to oil and gas, the Land Use Act, 1978 and aspects dealing with the oil laws of Nigeria has given sweeping powers to the government to expropriate land for use by the oil industry without due process or adequate compensation, in contravention of its international human rights obligations, in particular, the right to an adequate standard of living. ${ }^{29}$ The provisions of these laws, which significantly undermine communities' security of tenure, also create the legal foundations for oil companies to operate without due regard for the impacts of their operations on human rights. The result is the conflict between the communities and the oil companies over land. Companies depend on land because the oil is beneath it, while communities depend on land for farming and fishing. ${ }^{30}$ However, in almost every respect, the human rights of the people of the Niger Delta have been undermined by the laws enacted to allow oil and gas extraction to occur.

this Act, the court shall award such compensation as it considers just in respect of any damage done to any buildings, lion crops or profitable trees by the holder of the permit in the exercise of his rights there under and in addition may award such sum in respect of disturbance (if any) as it may consider just." In practice the tendency has been to focus compensation calculations on the surface goods lost under the headings of crops, economic trees and buildings.).

${ }^{28} \S 47$ (2) states: "No court shall have jurisdiction to inquire into any question concerning or pertaining to the amount or adequacy of any compensation paid or to be paid under this Act."

${ }^{29}$ U.N. International Covenant on Economic, Social and Cultural Rights, art. 11, GAR 220A (Dec. 16, 1996).

30 G. F. Frynas, OIL IN Nigeria: CONFLICT AND Litigation BETWEEN OIL COMPANIES AND VILlAGE COMMUNITIES 170 (2000). 


\section{Violation of Constitutionally Guaranteed Rights by Transnational Oil Corporations in Nigeria}

It is an irony that some of the rights violated by the TNCs in connivance with the federal government of Nigeria as part of their oil operation activities in the Niger Delta region are rights constitutionally guaranteed by the same Government of Nigeria for which the operators of this Constitution have vowed to protect at the time of taking their oath of office. For example, the right to life is enshrined under Section 33 of the Constitution and it provides that, "Every person has a right to life, and no one shall be deprived intentionally of his right, save in execution of the sentence of a court in respect of criminal offence for which he has been found guilty in Nigeria"31. Again Section 34 provides that, "every individual is entitled to respect for the dignity of his person, and accordingly, no person shall be subjected to torture, or to inhuman or degrading treatment, no person shall be held in slavery or servitude, and no person shall be required to perform forced or compulsory labour". 32

Section 20 of the Constitution of Nigeria states that, "the state shall protect and improve the environment and safeguard the water, air, and land, forest and wild life of Nigeria". ${ }^{33}$ Therefore the state is under the responsibility to protect the environment of Nigeria in the event of violation of the rights to decent environment by the transnational oil corporations. It is not an excuse that this responsibility is not under fundamental human rights provisions of the Constitution which are enforceable in the courts of law. States which have given each other undertaking to respect, protect and promote human rights in the form of international human rights conventions must implement this self imposed obligation in national legislation. In 1986 a group of human rights experts in the United Nations specified this responsibility of states in the so called Limburg principles. These specify that states have:

31 FED. REP. OF NigERIA CONST. § 33(1).

32 Id. $\S 34(1)$.

33 Id. $\S 20$.

12 
- a duty of respect: the state is obliged to refrain from infringement of rights;

- a duty of protection: the state must protect rights against infringements by third parties (like TNCs); and

- a duty of implementation: the state must ensure complete realisation of human rights where this is not already the case. ${ }^{34}$

Notwithstanding, states responsibility to promote and protect human rights, companies clearly also have a role to play in supporting and disseminating human rights. The Universal Declaration of Human Rights, 1948 calls on every individual and every organ of the society, which obviously includes transnational corporations and other business players, to contribute to the realisation of human rights. ${ }^{35}$ The Universal Declaration of Human Rights, 1948, in which the obligation to promote respect for human rights and to secure their universal and effective recognition and observance is addressed not only to states but also to 'every individual and every organ of society', a formulation wide enough to encompass private corporations. ${ }^{36}$ By so doing, multinational enterprises are meeting their moral and economic obligation to promote worldwide realisation of human rights and to contribute to their recognition through observance. Hence in April 2008, the UN special representative John Ruggie proposed a concept for human rights and companies which he classified into three principles: protect, respect and remedy. ${ }^{37}$ It is the duty of the state

34 Confederation of German Employers' Associations (BDA), Human Rights and Multinational Enterprises: Possibilities and Limits of What Business Can Do 10 (May 2008).

35 Id. See also Universal Declaration of Human Rights art. 29(1) (although not legally binding at the time it was adopted, many argue that "subsequent state practice has transformed it into a document considered by many to be a statement of customary international law").

36 Peter T. Muchlinski., Human Rights and Multinationals: Is there a Problem?, 77 (1) International Affairs 40, 31-48 (2001); See also Amnesty International Dutch Section and Pax Christi International, Multinational Enterprises an-d Human Rights (Utrecht, November 1998), at 33-34.

${ }^{37}$ U.N. Human Rights Council, Protect, Respect and Remedy: A Framework for Business and Human Rights. Report of the Special Representative of the Secretary-General on the Issue of Human Rights and Transnational Corporations 
to protect the people within its borders against human rights infringements by non state players. It is the duty of companies to respect human rights and to put in place the management structures necessary to this end and judicial and non judicial grievance mechanisms need to be developed and reinforced in order to improve defence against human rights infringement. 38

Though Section 20 of the Constitution of Nigeria, 1999, is a part of the fundamental objectives and directive principles of state policy and thus not justiciable and enforceable by courts of law but judicial pronouncements on matters of environmental pollution due to oil spillage and gas flaring in the Niger Delta region abound and has become precedents that could be considered as enforceable, like provisions of the extant constitution of Nigeria. A classical example is the case of Gbemre v. Shell Petroleum Development Corporation of Nigeria Ltd and Ors. ${ }^{39}$ in which a strong judicial precedent was established. This case was brought by Jonah Gbemre on behalf of himself and the Iwhereken Community in Delta State, in the Niger Delta area of Nigeria against Shell Petroleum Development Company Nigeria Ltd, the Nigerian National Petroleum Corporation (hereinafter referred to as "NNPC") and the Attorney General of the federation. The case was brought under the fundamental rights enforcement procedure in the Nigerian constitution, alleging violations of both constitutional provisions and the African Charter. The plaintiffs claimed that the oil exploration and production activities of Shell, which led to incessant gas flaring, had violated the right to life and dignity of

and Other Business Enterprises, April 7, 2008, available at http://www2.ohchr.org/english/bodies/hrcouncil/8session/ reports.htm. (last visited Aug. 5, 2012).

38 See John Ruggie, Business and Human Rights: The Evolving International Agenda, 4 (John F. Kennedy School of Government Working Paper RWP07-029, June 2007), available at http:// ksgnotes1.harvard.edu/Research/wpaper.nsf/rwp/RWP07-029. See also John Ruggie, Standards and Practices- Guiding Principles for Business and Human Rights, Ethical Corporation, (Oct. 2007),http:// www.ethicalcorp.com/ content.asp?ContentID=5353.

39 Jonah Gbemre v. Shell Petroleum Development Corporation of Nigeria Ltd and Ors., No. FHC/ B/CS/53/05, Federal High Court, Benin Judicial Division (Nov. 14, 2005). 
the human person under Sections 33(1) and 34(1) of the Constitution of Nigeria, 1999 and Articles 4, 16 and 24 of the African Charter. ${ }^{40}$ The plaintiffs alleged that the continuous gas flaring by the company had led to poisoning and pollution of the environment which exposed the community to the risk of premature death, respiratory illnesses, asthma and cancer. They also alleged that the pollution had affected their crop production thereby adversely affecting their food security. They claimed that many of the natives had died and many more were suffering from various illnesses. The community was therefore left in a state of gross underdevelopment. The defendants opposed the case on several grounds, including that those Articles of the African Charter do not create enforceable rights under the Nigerian fundamental rights enforcement procedure. However, they failed to follow up their arguments during the proceedings due to procedural issues.

The judge therefore proceeded to judgment without any findings of fact. The court held that the constitutionally protected rights include right to a clean, pollution free environment and that the actions of Shell in continuing to flare gas in the course of its oil exploration and production activities in the plaintiffs' community violated their right to life and/or the dignity of the human person under the Constitution and the African Charter. Even though there is no apparent justiciable right to a 'clean poison free, pollution free and healthy environment' under the Nigerian constitution, the court relied on a cumulative use of constitutional provisions with the provisions of the African Charter (especially Article 24) to recognize and apply a fundamental right to a 'clean poison free, pollution free and healthy environment'. The implication of this decision is that there is a possibility of resorting to the African Charter for Rights which are not available under national law. The plaintiffs' counsel further argued that the provisions of the Associated Gas Reinjection Act (Continued Flaring of Gas Regulations) 1984 and The Associated Gas Re-Injection (Amendment) Decree No. 7 of 1985 which allow for continuation of gas flaring are inconsistent with the right to life (which includes the

40 African (Banjul) Charter on Human and Peoples' Rights art. 4, 16, 24, O.A.U Doc CAB/LEG/67/3 Rev. 5, (1982) 21 I.L.M. 58. 
right to a healthy environment) guaranteed under the Constitution. The court agreed with this argument and held that legislation permitting flaring of gas in Nigeria, with or without permission, is inconsistent with the Nigerian Constitution and, therefore, unconstitutional. The court therefore directed the Attorney General of the federation and the Minister of Justice to take steps to amend relevant legislations governing gas flaring to bring them in line with provisions on fundamental rights under the Nigerian Constitution. The significance of this is that fundamental rights protection is held as an objective which other regulations must meet in order to be valid under the law. This clearly invalidates the discretion given by extant legislation to the government to permit gas flaring as it deems fit. The court consequently restrained the company from further gas flaring in the plaintiffs' community. ${ }^{41}$

\section{Measures that can be Adopted for Effective Protection of Human Rights in Niger Delta Region}

In the face of weak regulatory framework to check the activities of transnational corporation for human rights violations in the Niger Delta region of Nigeria, the government of Nigeria should strengthen its regulatory mechanism by enacting effective human rights laws to curb human rights violations. This is because business enterprises, particularly transnational companies, are typically private, non governmental entities subject only to national laws in either the country where the company has its headquarters or in the host countries where the company has investments. Even though these companies may have significant presence in multiple countries, they are not technically considered to have international legal status, which is limited to states and certain intergovernmental organizations such as the European Union and the United Nations. This means that they are not subject to the

\footnotetext{
41 See also Olufemi O. Amao, Corporate Social Responsibility, Multinational Corporations and the Law in Nigeria: Controlling Multinationals in Host States, 52 JOURNAL OF AFRICAN LAW 89, 110-111 (2008). 
rights and obligations of international law, including international human rights law. ${ }^{42}$

Oil companies in Nigeria are under federal jurisdiction. The federal government is both a partner in all oil activities through NNPC, and is required by federal law to enforce environmental compliance of oil operations through the Department of Petroleum Resources. This situation has resulted in the government inadequately regulating oil pollution while at the same time being part to much of the Delta. The major constraints impending reduced oil pollution are (i) the conflict of interest for the Federal government being both a partner in oil activities and the regulatory body. (ii) no requirement for community participation in planning and development of oil activities. (iii) very limited ability of regulatory institutions to monitor pollution. (iv) low compensation rates for damage to property; and (v) lack of enforcement of environmental regulations. ${ }^{43}$ There is a practical need for home states to control the activities of their corporations when host states like Nigeria prove unwilling or unable to do so because of lax laws or the revenue derived from the operations of these TNCs.

The transnational oil corporations in Nigeria should be made accountable for human right violations committed by them, their subsidiaries or contractors, in their operational bids in the Niger Delta. Extraterritorial avenues such as the Alien Tort Claims Act, 1789 should be invoked where the action is a grave violation of customary international law. ${ }^{44}$ This was exemplified in the case of

42 Jana Silverman \& Alvaro Orsatti., Holding Transnational Corporations Accountable for Human Rights Obligations: The Role of Civil Society, Social Watch 33, www.socialwatch.org/sites/default/files/silvermanorsatti2009_eng.pdf (last visited Feb. 6, 2012).

43 Tari Dadiowei, Environmental Impact Assessment and Sustainable Development in the Niger Delta: The Gbarain Oil Field Experience 33, Institute of International Studies, University of California, Berkeley, USA, Working Paper No.24, 2009); See, World Bank (1995). Defining an Environmental Development Strategy for the Niger Delta, World Bank, Washington DC Western And Central Africa Department, Industry and Energy Operations Division, Vol. 11, 53.

44 See Ramasastry, Corporate Complicity: From Nuremberg to Rangoon, An Examination of Forced Labour Cases and their Impact on the Liability of 
Wiwa v. Royal Dutch Petroleum Co. 45 where it was held that the TNCs are liable for human rights abuses occurring in the context of their business activities abroad.

The home governments of TNCs should become proactively engaged in compelling their oil companies to change their corrupt, exploitative, destabilising, intimidating, instigating, brutalising, and destructive business practices in Niger Delta. While the government of Nigeria and the transnational oil corporations should use their diplomatic and economic leverage to persuade Niger Deltans or the host communities in the event of conflict with the business practices of the oil companies without using military means to solve problems which eventually result in fatal casualties involving loss of lives and properties. Efforts should be made by Nigerian government to end gas flaring by oil companies, through legislation. In Europe and America, gas flaring has been eliminated. It is, therefore, recommended that the directive that gas flaring should stop in Nigeria by 2008 has to be complied with by all the stakeholders. ${ }^{46}$

Observing the provisions of Universal Declaration of Human Rights, 1948, and the International Covenants on Human Rights, $1966^{47}$ as the set standards for operation of the TNCs in Niger Delta

Multinational Corporations, 20 BERKELEY J. INT'L L. 91, 96- 101 (2002) (ATCA cases are pursued under customary international law. Under customary international law, natural persons (individuals) have a duty not to violate fundamental or peremptory norms (including piracy, aircraft hijacking, forced labour, genocide, war crimes and crimes against humanity). This has led some to conclude that: 'To the extent that individuals have rights and duties under customary international law and international humanitarian law, multinational corporations as legal persons have the same set of rights and duties. ATCA is an example of a national jurisdiction treating corporations in the same way as natural persons with regard to international customary law).

${ }^{45}$ Wiwa v. Royal Dutch Petroleum Co., 226 F.3d 88 (2nd Cir. 2000); Wiwa v. Royal Dutch Petroleum Co., 2002 U.S. Dist. LEXIS 3293 (S.D.N.Y. 2002). ${ }^{46}$ H.T. Ejibunu, Nigeria's Niger Delta Crisis: Root Causes of Peacelessness 33, 34 (2007) (EPU Research Papers, Issue 07/07 European University Center for Peace Studies (EPU), Presentation of 2007 Stadtschlaining/Austria).

${ }^{47}$ International Covenant on Civil and Political Rights art. 6(1), G.A. Res. 2200A (XXI), U.N. GAOR Supp. No. 16, U.N. Doc. A/6316, at 52 (Dec. 16, 18 
is greatly recommended. There is a need to spell out clearly for transnational corporations in Nigeria what these human right instruments require of their firms. The United Nations Norms on the Responsibilities of Transnational Corporations and Other Business Enterprises with Regard to Human Rights, adopted by the UN Sub Commission on Human Rights in 2003, set out with some degree of specificity the human right responsibilities of companies. 48

Finally, oil companies operating in Nigeria should align their actions on voluntary commitments to a range of internationally agreed principles and instruments dealing with human rights. Examples are the OECD guidelines for multinational enterprises, ${ }^{49}$ the ILO tripartite declaration concerning multinational enterprises and social policy ${ }^{50}$ and the Global Compact. ${ }^{51}$

1966); International Covenant on Economic, Social, and Cultural Rights, G.A. Res. 2200A (XXI), U.N. GAOR Supp. No. 16, U.N. Doc. A/6316, at 49 (Dec. 16, 1966).

48 Norms on the Responsibilities of Transnational Corporations and Other Business Enterprises with Regard to Human Rights, U.N. Doc. E/CN.4/Sub.2/2003/12/Rev.2 (2003), available at http:// www1.umn.edu/ humanrts/links/norms-Aug2003.html (last visited Feb. 2, 2013).

49 OECD Guidelines for Multinational Enterprises, 19 (Aug. 7, 2012)http://www.oecd.org/dataoecd/56/36/1922428.pdf. (the OECD Guidelines for Multinational Enterprises recommends that firms "respect the human rights of those affected by their activities consistent with the host government's obligations and commitments." For example, the OECD created complaint mechanisms called "National Contact Points" to which individuals may bring complaints against businesses subscribing to the OECD Guidelines, and tasked its Investment Committee with overseeing National Contact Points (NCP) performance.).

50 Tripartite Declaration of Principles Concerning Multinational Enterprises \& Social Policy, adopted by the Governing Body of the International Labour Office at its 204 ${ }^{\text {th }}$ session (Geneva, November 1977) as amended as its 297th Session 3, 8 (Nov. 2000), available at http:/ / www.ilo.org/public/english/employment/multi/download/ english.pdf. (last visited Aug. 7, 2012) (all parties, including multinational enterprises, should respect the Universal Declaration of Human Rights and the corresponding international Covenants). 


\section{Conclusion}

Transnational oil companies should actively promote the realisation of human rights in business transactions. In the context of the corporate social responsibility, they owe a duty towards the protection of human rights. With their own voluntary initiatives, multinational enterprises can make a contribution for better implementation of human rights partly in the framework of public private partnerships or jointly with non-governmental organisations. TNCs should create a platform to give all employees the possibility to set out their views on how human rights policy, including compliance with social standards within the undertaking, can be better implemented. Oil companies in Niger Delta should engage in dialogue with governments for better implementation of human rights and work locally in contact with national administrative agencies for more effective enforcement of social standards in their spheres of activity.

51 See supra note 39 at 13, 14. (The UN Global Compact, is a voluntary initiative established in 2000 with over 2,300 participating businesses. The Global Compact encourages its members to implement ten principles touching on human rights, labour standards, environmental, and anticorruption practices within their "spheres of influence" by sharing and adopting good practices. The Global Compact asks businesses to "respect the protection of internationally proclaimed human rights" within their sphere of influence, "make sure that they are not complicit in human rights abuses," and to respect the four fundamental labour rights principles adopted by the ILO); See also The U. N. Global Compact, http://www.unglobalcompact.org/AboutTheGC/heTenPrinciples/index .html, (last visited Aug. 7, 2012); See Broecker, supra note 14 at 169, 170. 